\title{
Financial Inclusion: A Veritable Tool For Inclusive Growth And Poverty Alleviation In Nigeria
}

\author{
0. S. Uwakaeme, Ph.D \\ Department of Banking and Finance \\ Madonna University Nigeria, Okija Campus, \\ Anambra State
}

\begin{abstract}
In recent times, inclusive growth has become a national policy objective worldwide. In the context of Nigeria's growth planning, it is a relatively new terminology which got the attention of policy makers in October 2012.Inclusive growth has the literal meaning of the two words that refers to both the pace and the pattern of the economic growth. It basically means, broad based, shared, and pro-poor growth. In Nigeria, the formal financial system provides services to about $35 \%$ of the economically active population while the remaining $65 \%$ are excluded from access to financial services. These $65 \%$ are often served by the informal financial sector some of which are not regulated. The non-regulation of the activities of the informal sector has serious implications for the Central Bank of Nigeria's ability to exercise its mandate of promoting monetary stability and sound financial system. Economic growth and development in any economy is propelled by the quality of goods and services provided within that economy as well as their competiveness with other economies. One of the major factors that have constrained the pace of economic growth and development is lack of access to sustainable financial services by a greater proportion of the populace. Inclusive growth will follow at a faster pace when every segment of the populace engages in the productive process through access to sustainable financial services. Access to financial services could assist to alleviate poverty and promote both growth and standard of living when the economic active-poor and the disadvantaged are enabled to save, borrow and reinvest for the growth of the real sector of the economy. In this, paper an effort has been made to understand the inclusive growth phenomenon, its need and sustainable financial inclusion as a veritable tool to attain it, relative to Nigerian experience.
\end{abstract}

Key Word: Financial Inclusion, Inclusive Growth, National policy and Poverty-alleviation.

\section{INTRODUCTION}

A formal and stable financial system is prerequisite to economic growth and development. The operations of such system are crucial to peoples' savings, credit, payment and risk management needs. A robust economic growth cannot be achieved without putting in place well focused programmes to reduce poverty through empowering the people especially the active-poor and the disadvantaged within the economy. This could be achieved by increasing their access to sustainable financial services especially credit to enhance production capacity. The latent capacity of the economically active-poor for entrepreneurship would be significantly enhanced through provision of financial inclusion activities to enable them engage in economic activities and be more self-reliant, increase employment opportunities, enhance household income and create wealth.

Financial Inclusion is simply the delivery of financial services at affordable costs to sections of disadvantaged and low-income segments of society, in contrast to financial exclusion where those services are not available or affordable. In other words, it is the provision of a broad range of high quality financial products, such as savings, credit, insurance, payments and 
pensions, which are relevant, appropriate and affordable for the entire adult population, and especially the low income segment.

A Report on Financial Inclusion by the World Bank which was last updated on $5^{\text {th }}$ April, 2017 revealed that an estimated two billion working-age adults (more than half of the world's total adult population) do not have an account at a formal financial institution. Financial Inclusion efforts seek to ensure that all households and businesses, regardless of income level, have access to and can effectively use the appropriate financial services they need to improve their standard of living. Inclusion in the formal financial system helps people carry out day-to-day transactions, including sending and receiving money, safeguard savings (which can help households manage cash flow spikes), smooth consumption and build working capital, finance small businesses or microenterprises, help owners invest in assets and grow their businesses, plan and pay for recurring expenses, such as school fees, mitigate shocks and manage expenses related to unexpected events such as medical emergencies, a death in the family, theft ,or natural disasters, and improve overall welfare. The benefits of Financial Inclusion are not only significant for individuals but for economies as well. Financial Inclusion is linked to a country's economic and social development, and plays a role in alleviating extreme poverty. According to a World Bank report on Financial Inclusion, there cent increase in Financial Inclusion is due to "immense supportive and competitive environments, policies that encourage innovation and national Financial Inclusion strategies". These initiatives were driven by mobile technology, digital payments and law reforms that encourage correspondent banking and relaxed customer identification. The Securities in Moveable Assets Act 2017 is one of such laws recently enacted to promote access to financial services in Nigeria. The provisions of the Act compel banks to accept movable assets as collateral when granting loans to Micro, Small and Medium Enterprises ("MSMEs") as well as other Nigerians. In addition, with the prevalence of mobile phones, mobile money is playing a crucial role in extending financial services to the underserved.

In the definition of financial inclusion, the Centre for financial inclusion defines a full financial inclusion as " A state in which all people who can use financial services have access to a suite of quality financial services, provided at an affordable prices, in a convenient manner, and with dignity for clients" (Gardeva and Rynne, (2011).[18]. This entails building a stable financial system that would serve as many people as possible. (Afi, 2010) [03]

Inclusive growth confers many benefits which include raising the general standard of living of the populace as measured by per capita national income; making income distribution easier to achieve; and enhancing the time frame of accomplishing the basic needs of man to a substantial majority of the populace while economic stagnation can bring destabilizing consequences on the citizenry. Economic growth and development of any country is propelled by the quality and quantity of goods and services provided within the economy as well as the competitiveness with other countries. When every segment of the populace engages in the productive process, growth and development will be enhanced at a faster pace. Empowerment for economic engagement is created through the instrument of financial services. Financial services required by the populace vary, depending on the economic stratum or level of development to which one belongs. Access to sustainable financial services by the economically active -poor and the disadvantaged group of the society could assist to alleviate poverty and promote development by enabling them to save, borrow and reinvest to the growth of the economy.

Consequently financial inclusion, by providing access to financial services for the excluded group would increase production capacity for goods and services, support reduction of food 
related inflation, gives rise to the use of low cost financial services, efficient financial services and ultimately reduction in poverty. Financial inclusion will also create a diversification of the portfolio of financial institutions by bringing in the excluded group and this step will strengthen portfolio risk management stance. Financial literacy which is an important component of financial inclusion will also enhance better financial services delivery by educating the targeted excluded group thereby creating a well- informed financial services providers and users .The combined effect of these financial inclusion activities will enhance institutional viability, safety and soundness of the financial system. It will also lead to increasing economic activities and employment opportunity for rural household, raise the standard of living of the excluded with possible positive multiplier effect on the economy. Consequently, financial inclusion, when promoted in a broader context of economic financial inclusion can be a tool for economic growth and poverty alleviation.

Conversely, there is a heightened interest in financial inclusion by developing economies world over because a greater proportion of the populace consists of the excluded and disadvantaged group and Nigeria is not left out. Many studies have established that financial development tends to increase economic growth and reduce inequality of income and poverty. (Goldsmith,(1969)[20] as well as World Bank (2008 and 2014). [34 and 35]. This is because improvement in the financial sector is expected to aid savings and capital formation, ease external financial constraint that accompanies external borrowing and finally higher growth is obtained. (Greenwood and Javanovic (1990).[21]

Nigeria is described as the giant of Africa with vast mineral resources, favourable climate and vegetation. Despite these very good potentials, she has not been counted among the largest and fastest growing economies of the world. Her performance in terms of economic growth has been very volatile and sluggish. What has been the most challenging fact about her growth is that her growth has not only been uneven, but also discrete. It has been uneven in the sense that there has been no uniformity in her growth performance and it has been discrete and disconnected with regard to growth and distribution of growth benefits to certain sectors of the economy. It is glaring clear that a vast majority of the population remained outside of basic health and education facilities even during when she recorded high growth phase. In recent decades, economic and social inequalities have increased alongside high growth rates which have increased regional inequalities.

Nigeria, with a population of approximately 2 million, has a formal financial system that provides services to about $35 \%$ of the economically active population while the remaining $65 \%$ are excluded from access to financial services. These 65\%are often served by the informal financial sector through Non-governmental Organizations, microfinance institutions, money lenders, credit unions, friends and relatives at a very exorbitant cost. The non-regulation of the activities of some of the informal sector has serious implication for the Central Bank of Nigeria's (CBN) ability to exercise one of its mandate of promoting monetary stability and sound financial system. (CBN, 2005) [11]

In the past, in order to enhance the flow of financial services to Nigeria's rural areas, Government has initiated a series of publicly-financed micro/rural credit programmes and policies targeted at the poor. Notably among them were the Rural Banking Programme, sectorial allocation of credits, concessionary interest rate, and the Agricultural Credit Guarantee Scheme. Other institutional arrangements were the establishment of the Nigerian Agricultural and Cooperative Bank limited, (NACB), People's Bank of Nigeria, (PBN), the Community Banks, the National Directorate for Employment (NDE), and the Family Economic Advancement Programme, (FEAP) etc. In the year 2000, the Government merged the NACB 
with PBN and FEAP to form the Nigerian Agricultural Co-operative and Rural Development Bank Ltd (NACRDB) while Micro Finance Banks took over the services of both Community and Peoples Bank of Nigeria in 2005. (CBN, 2005) [11].All these were geared towards poverty alleviation and expansion of financial services delivery to the rural areas and most specifically to the economically active poor and the disadvantaged group but the effects were short-lived due to unsustainable nature of the programmes.

Furthermore, in the recent times, the Nigerian financial sector has witnessed a significant financial development as both the government and the operators in the sector have instituted policies and strategies for its expansion. Although most of these policies and strategies have been targeted at financial inclusion, the impact of this development is yet to be reflected in the growth and development of her real economy. For instance, majority of Nigerian Small and Medium Enterprises (SME) (over 80\%) still describe poor access to financial services, as their most difficult problem. (NSB.SMEDAN,(2012).[28] It has also been documented that financial development indicators such as credit to the private sector have no significant impact on the general economic and structural growth of Nigeria's economy. (Shittu, 2012) [30] as well as (Afangideh, 2010). [02] It is therefore not surprising that Nigeria ranks low in the financial inclusion indicators even among her peers. The World Bank Global index data shows that about $30 \%$ of Nigerian adults have accounts with the formal financial institutions. (World Bank, 2008) [34]. This value is below that of Kenya and South Africa which have values of $42 \%$ and 54\% respectively. (Demirguc-Kunt and Klapper (2012) [16]

Definitely, when financial development is not being inclusive, especially when it tilts heavily towards the wealthy, (as in the case of Nigeria) it may dampen economic growth. This perhaps may explain why financial development of developing economies has not effectively been translated to growth. It has also been shown that in countries with low level of financial inclusion, households, Small and Medium Enterprises (SME) and other disadvantaged group resort to the informal financial sector for financing at all cost and this can be counterproductive. (Collins et al, 2009) [14]. In the light of the above discussions, many countries have come to recognize the potentials of financial inclusive system which is now increasingly becoming a political issues to financial markets, regulators, and operators. (AFI, 2010) [03].

Consequently, as a part of Nigeria's efforts to address the problem of low level of financial inclusion, she has put together a National financial inclusion strategy which is designed to increase the number of Nigerians which are included in the formal financial system to $70 \%$ by year 2020. (CBN, 2012) [12]. One of the important aspects of this strategy is the issue of monitoring, evaluation, creating awareness and understanding the financial inclusion phenomenon and the importance of it in economic growth and poverty alleviation. This is to ensure that the strategy will be sustained and will make a desired impact on the populace especially on the economically active poor and the disadvantaged groups. (CBN, 2012) [12].

For a large and developing economy like Nigeria, it is pertinent to ensure that measures of the extent of financial inclusion encompass different parameters that properly reflect the complexity and diversity of the country, taking into consideration the economically- active poor and the disadvantaged group within Nigerian context. For instance, although measures and data provided by international organisations have the advantages of providing standardised cross-country comparisons, they may not reflect the peculiarity of the local economy and the level of her financial system development. There is therefore need to depend on the policy goals and settings of the financial development of the country involved 
and also keep the excluded abreast of the new ideas based on the evolving needs of the financial inclusion strategy adopted by the country in question (Chakrabarty, 2012). [13]. In the light of the above and in line with the Nigerian government strategy on financial inclusion, the broad objective of this paper is to establish a link on how inclusion initiatives can help the economically active poor and the disadvantaged embrace the formal financial system thereby reducing poverty in the economy. In addition, financial inclusion comparisons are made with some selected countries as well as efforts to explain differences in the extent of financial inclusions among the countries. The specific objectives of this paper include: To study and understand the meaning and need for inclusive growth; to understand the role and importance of financial inclusion in inclusive growth; to know the extent of financial exclusion/inclusion in Nigeria; and to make recommendations on how sustainable financial inclusion could be a veritable tool to attain the inclusive growth and poverty alleviation in Nigeria

\section{THE CONCEPT OF FINANCIAL INCLUSION AND GROWTH}

Financial inclusion refers to delivery of financial services at an affordable cost in a fair and transparent terms and conditions to vast groups of disadvantaged, weaker and low income groups including household enterprise, small medium enterprise and traders. It not only enhances overall financial intensity of agriculture but also help in increasing rural non-farm activities which lead to development of rural economy and improve economic condition of people. Financial inclusion activities include micro credit, branchless banking, saving products, pension for old age, microfinance, self help group, entrepreneurial credit etc.

However, the concept of financial inclusion has often been defined in the context of the institutional settings and goals of the economic policy of the country involved; hence does not enhance standardization and cross-country comparisons. Consequently the concept of financial inclusion has been described in various contexts depending on perceived peculiarities of the economy in question. Wikipedia Encyclopaedia defines it as the delivery of financial services at affordable cost to low-income and disadvantaged segments of the society. The Centre for Financial Inclusion offers a broader vision of it. It defines "Full-financial inclusion" as a state in which all people who can use financial services have access to a complement of quality financial services, provided at affordable prices, in a convenient manner and with dignity of the clients". This definition recognises diversity in the institutional providers, services offered and users of financial services. The Reserve Bank of India defines it as the delivery of financial services at affordable cost to vast section of the disadvantaged and low-income groups. (RBI, 2013) [08] It identified the services to include credit, savings, insurance, payments and remittances. The Nigerian National Financial Inclusion Strategy defines it u-as a state where adult Nigerians have access to a broad range of financial services that meet their needs at affordable costs. The United Nations Development Programme (UNDP) views on inclusive financial system as one that services all clients, which means reaching out to the poor and to low-income people and providing them with affordable financial services tailored to their needs. It further views an inclusive financial system as one that recognizes the market potentials/income generating opportunities in lending to the poor but excluded population. Economic growth is a key policy objective of any government and economic policy through financial inclusion is a major instrument for attainment of such objective. Economic growth could be referred to as a sustained and positive change in the level of aggregate goods and services produced by a country over certain and given period of time. When economic growth is measured over the population of a given country, it can be stated in terms of per capita income, according to the aggregate goods and services produced in a given year which is divided by the population of the country within that given period. The higher the per capita income of the populace, the less is the poverty indicators within the economy. It can be stated in nominal or in real terms. Based on this, when the increase in the aggregate level of goods 
and services is deflated by the rate of inflation, real economic growth is achieved, but when it is measured without deflating, it is referred to as nominal economic growth.

Economic growth raises the general standard of living of the population as measured by per capita national income; makes many kinds of income distribution easier to achieve; enhances the time frame of accomplishing the basic necessities of man, like shelter, food, clothing etc, by a substantial majority of the populace and rapid growth rates are often associated with efficient economic and political systems or even prestige, Lipsey, (1982) [24]. However, the concept of economic growth has not been quite easy to understand and likewise its measurements in real terms. This is because in most literature of economics, some authors have differentiated economic growth from the term economic development in different ways. Authors like Todaro (1980)[31] and Baran (1968) [09] argue that the mere increase in the aggregate level of goods and services produced in a country, tells nothing about the quality of life of a citizenry given the threats of global pollution, abysmal lop-sided distribution of aggregate income, environmental degradation, prevalence of chronic and deadly diseases and absence of freedom and justice. These authors believe that attention should be focused not merely on increase in aggregate output and income but also on the total quality and standard of living of the citizenry especially the economically-active poor and the disadvantaged group. Nevertheless, it is evident that there is yet no satisfactory measure of "quality of life" that can be applied to quantitative measure of aggregate output and income, that would be acceptable to all and sundry that could stand the test of time. The apparent consensus suggests that economic growth refers to an increase in the aggregate level of output within a given time period in a country while economic development is seen as an increase in the aggregate level of output and incomes with due consideration given to the quality of life that hopefully takes into consideration the distribution of income, health care, environmental degradation, global pollution, freedom and justice, etc. Generally, economic development is a process by which an economy experiences three main phenomena namely: growth in output, structural changes and institutional changes. If the three phenomena take place, it will lead to a rise in standard of living of the populace. Hence that explains why growth could be enjoyed by many economies but not all experience development. (Uwakaeme, (2015) [33]

Inclusive growth embraces both the economic growth and development. In recent decades, economic and social inequalities have increased alongside high growth rates which have increased regional inequalities. Rapid and sustained poverty reduction requires inclusive growth that allows people to contribute to and benefit from economic growth, but for this growth to be sustainable in the long run, it should be broad-based across sectors, and inclusive of the large part of the country's labour force. As a result, Inclusive growth has become a national policy objective worldwide. In some developing economies, it is a relatively new terminology which got the attention of policy makers in recent times. Inclusive growth has the literal meaning of the two words which refers to both the pace and the pattern of the economic growth and it basically means, broad based, shared, and pro-poor growth. In most developing countries, financial inclusion has been adjudged as a veritable tool to achieve inclusive growth (World Bank, 2008) [34].

\section{Financial Inclusion: Inclusive Growth and Poverty Alleviation:}

It is a proven fact that financial inclusion and financial literacy is an effective way for "Poverty Alleviation". The objective of financial inclusion is to meet the expectation of the unbanked and excluded, yet silent mass of the population are untouched, mostly in developing economies. Poverty and exclusion continue to dominate socioeconomic and political discourse in Nigeria over the last several decades. Despite being the giant of Africa, Nigeria is still a home to one- 
third of the worlds poor. Financial inclusion has the potential to enhance the socioeconomic condition of the lowest active poor. Inclusive financing is to deliver financial services at affordable cost to low income segment of society in contrast to financial exclusion. They bridge up the gap between the weaker sections of society and the sources of livelihood and the means of income which can be generated for them if they get loans and advances. Once the weaker section of society gets some money in loan form, they can start up their own business or they can support their education through which they can sustain their livelihood. Thus financial inclusion turns out to be benefit for the low income households. To serve the requirements of the large section of society, there is an urgent need for the larger market for the financial system which opens up the avenues for the new players in the financial sector and can lead to growth of banking sector also.

The importance of financial inclusion is that it reduces the gap between the different sections of the society. It enhances reduction in the poverty levels and unemployment and increases awareness about the financial products of the financial institutions involved. Financial inclusion helps in reduction of regional or social disparity as well as increasing the investment for infrastructure within the economy. Thus financial inclusion acts as an imperative tool for inclusive growth and poverty alleviation.

\section{RELATED REVIEWED STUDIES}

Different studies have, at different times, investigated the effect of financial inclusion on inclusive growth and development in different economies. For instance, Cyn-Young and Ragelio (2015) [15] examined the relationship between financial inclusions, poverty and income inequality in Asia. The study which focused on developing Asian economies sought to determine country-specific factors and macroeconomic variables that affect the level of financial inclusion for selected 37 developing Asian countries. They find that demographic factors and per capita income significantly affect financial inclusion. The study also shows that financial inclusion reduces income inequality and poverty. The study suggests that strong financial regulatory oversight, rule of law and enforcement of financial contract would improve financial inclusion efforts. Migap et al. (2013) [26] examined financial inclusion as a strategy for inclusive growth in Nigeria. The study compared Nigerian financial inclusion index with other emerging economies in the upper middle income strata. They find that Nigerian financial inclusion indicator is still shallow compared to emerging economies both within and outside Africa. The study suggests that active participation of media and educational institutions should be encouraged to promote financial literacy in Nigeria.

Nkwede (2015) [27] examined financial inclusion and economic growth in Africa, using Nigeria as a case study. Data for the study covered the period 1981 to 2013. The study shows a negative relationship between financial inclusion and growth of Nigerian economy. He attributes the finding to high level of financial exclusion of adults from financial services.

Onaolapo and Odetayo (2015), [29] studied financial inclusion in Nigeria from the perspective of microfinance banks using a survey design method. They find that access to financial services through microfinance institutions by less privileged people promotes employment generation, reduction in poverty and overall economic growth. Joseph and Varghese (2014) [22] studied the role of financial inclusion in the development of Indian economy. The study investigated the activities of five private sector banks and five state banks from June to November, 2013. Onsite and offsite ATM usage, number of bank branches, credit cards and debit cards per customers were used as proxies for financial inclusion variables focusing on rural and semiurban areas in India. They find that quite a number of people are still excluded from financial services even after the introduction of inclusive banking initiatives in the country. 
Aduda and Kulanda (2012) [01] examined financial inclusion and financial sector stability with reference to Kenyan economy. The study which is exploratory in nature reveals that financial inclusion is a prerequisite for economic growth and development in Kenya because various financial inclusion programmes have impact on Kenya financial stability. The study suggests that government should intensify its financial inclusion strategies so that more people would have access to financial services especially people in the informal sector.

Similarly, Allen et al (2013) [05] revealed that commercial banks can enhance access to financial services to underprivileged households in Kenya by deepening its impact on the rural and vulnerable groups.

Brune et al (2011) [10] also find that increased financial access through mobilization of rural savings improves the livelihood of Malawian rural population because poor households have access to savings for agricultural inputs. World Bank (2008) [34] analysis shows that financial inclusion is also influenced by specific credit needs of various segment of people arising from a number activities such as housing, microenterprises and agriculture etc., due to difficulties in accessing formal sources of credit by the poor individuals together with small savings and internal resources to invest in housing, health, education, and other opportunities

Umma Dutse (2013) [32] analysed the role of Financial Literacy and Consumer Protection in fostering financial inclusion in Nigeria and stressed that literacy is a precondition to creating awareness of investment and growth in the economy. The study also pointed out the importance of a stable financial system which must include the public confidence and consumer protection as an ideal system. This implies that consumers of financial services should not be subjected to unfair or deceptive practices, should have access to information that could enable them make informed decisions and should have access to recourse mechanisms to resolve disputes.

Ajakaiye (2013) [04] in his contribution titled "Financial Inclusion in Nigeria: Measurement and Lessons" analysed the need to ensure sustainable measurement of the extent of financial inclusion, encompassing different parameters that properly reflect the complexity and diversity of the country. Thus, measurement and data provided by international organisations may have the advantage of providing standardised cross-border comparison but it should not be used for measuring the local stakeholders' financial inclusion activities but rather the measurement should reflect the specific institutional settings and goals of the financial development of the country that is involved. Eluhaiwe (2013) [17] focused on the role of financial inclusion initiatives on national economic development and the need and importance of financial inclusion that includes the poor and disadvantaged in the economy by allowing them access to sustainable financial services, thus enabling them to participate actively in productive activities which will enhance growth and development.

\section{AN OVERVIEW OF FINANCIAL INCLUSION STRATEGIES}

The need to bluntly reduce poverty alleviation through financial inclusion has accentuated the involvement of some global bodies. The Alliance for Financial Inclusion (AFI), a network of policy makers from developing and emerging countries, has been leading the struggle to promote inclusive finance over the years. Founded in 2008, AFI recognizes, adopts and promotes the propagation of effective financial policies in developing economies in an attempt to reach the 2.5 billion impoverished people across the globe. (CBN, 2012) [12]. AFI (2010) [03] also promotes peer learning among members to create room for interaction and exchange of knowledge on financial inclusion matters. Its activities have focused on consumer 
protection, mobile financial services, agent banking financial integrity, micro-savings data management, amongst others.

In addition, the G20 countries, in December, 2010 launched their Global Partnership for financial inclusion in Seoul, South Korea The partnership creates a platform for G20 countries and relevant stakeholders to foster financial inclusion. Their activities are being implemented through comprehensive action plan focused on financial sector reforms and development agenda. The Centre for Financial Inclusion has been helping to bring about conditions that would achieve worldwide financial inclusion through collaboration. The World Bank in particular is collaborating with Bill and Melinda Gates foundation and has constructed a Global Financial Inclusion Index (Findex); a data base that provides indicators for measuring the use of financial services across borders of economies and over time. Equally, various countries have been making commitment in their respective jurisdictions to promote financial inclusion. In 2012, about 95 AFI member institutions from across the Globe adopted the Maya Declaration on financial inclusion. Seventeen (17) of them pledged and made commitments at the AFI Global Plc Forum held in Riviera Maya, Mexico to pursue specific goals and targets on financial inclusion. It was at the event that Nigeria pledged to reduce her adult financial exclusion in the country from 46.3 in 2010 to 20\% in 2020 (Eluhaiwe (2013) [17]

The achievement of financial inclusion goals requires the participation of an array of institutions which service large scale, medium, small and micro enterprises. In many countries, commercial and investment banks provide financial services for industries and large scale enterprises. The medium and small scale enterprise category are served mostly by specialised institutions such as SME Banks, Agricultural Banks, and various guarantee and specialized financing arrangements. Those in the micro group have over years been served by informal financial institutions such as non-governmental organizations, financial cooperatives, credit unions and specially licensed microfinance banks. In order to arrive at appropriate financial inclusion strategies, policy makers have been converging at various for a to brainstorm best policy alternatives and propositions. This has, accordingly, resulted in the formulation of policies, guidelines as well as programme. The success of the initiatives varies from one country to another, depending on the environmental, social, political and cultural conditions within the economy. Diversity of financial products plays a critical role in financial inclusion initiatives. This is based on the fact that economic groups need diverse financial services. For instance, savings are needed for the rainy days, and reduction of vulnerability to adverse effect income vagaries. Savers also engage in investments that outweigh their balances, creating the needs for loans or credit. In many countries, institutions place a lien on savings as condition for extending loans or credit. In order to manage these uncertainties and mitigate the risk of external shocks, micro insurance products have also become part of financial services offered to poor clients. Small premium payments by individual clients are used to defray the loans of those who might default owing to natural occurrence such loss of crops and livestock due to diseases, ill health, fire and other natural hazards. Other services that are gaining prominence and acceptability include inventory collateralization, micro leasing, payment/remittance services and transfers. As financial inclusion programmes continue to attract increasing attention of stakeholders and policy makers, promoters are becoming concerned about critical factors that will ensure effectiveness and efficiency in services delivery. One of those factors is financial identity. Financial identity is being highlighted as a key risk management strategy in financial inclusion programmes. Given the low literacy levels of economically active-poor group in developing economies, and absolute lack of methods for registering subjects, financial identity presents a serious hurdle to financial inclusion. While large transaction wealthy clients might be able to provide their means of identifications such as identity cards from organisations or national identity cards, driving licensees and international passports, this 
does not apply to the poor and disadvantaged group. The need to simplify the financial identity procedure for poor group is pertinent to pave way for them to enter the financial market place. While striving to ensure access to financial services, the need to ensure that beneficiaries were protected from negative consequences of unethical practices of the services providers also comes to front burner. Areas of focus in this respect include ensuring that there is avoidance of over-indebtedness, fair interest charges, ethical conduct of staff of financial institutions, appropriate loan collection practices and procedures, secrecy of client data/information and fair methods of seeking redress in event of dispute. Many countries such as South Africa and the Philippines have embarked on aggressive financial education and literacy programmes, while others such Ghana are institutionalizing financial literacy programmes in their structural educational system. Financial system regulators, on their own part have been striving to maintain financial soundness and stability, encouraging the provision of sustainable and affordable financial services to the economically active poor and disadvantaged, and protecting the financial institutions' customers In order to fully capture the activities and initiatives of financial system and the intervening for the general good of the economy, many countries have been exploring various regulatory approaches. For instance, Cambodia employs a three tier approach to microfinance institutional practice. The first tier corresponds to the regulated institutions which were licensed and supervised by the country's central bank. The second, though not licenced, are registered by the Central bank and subjected to a light and simple regulatory ecosystem, while the third tier are those that carry out financial intermediation on a very low scale (the informal sector) and they are not registered nor regulated.

\section{Nigerian National Financial Inclusion Strategy}

The Nigerian National Financial Inclusion Strategy defines financial inclusion as "the process of improving access to a range of formal financial services and promoting the responsible usage of appropriate and affordable financial services to those sections of the society where the need exist." Access refers to the ease with which consumer can obtain financial services while usage refers to both uptake of appropriate products and services as well as how acquired services are used after initial acquisition. In Nigeria, the Central Bank of Nigeria (CBN), in collaboration with other stakeholders, launched the financial inclusion strategy in October 2012. The overall goal of the strategy is to increase the financial adult inclusion rate from $20 \%$ in 2010 to $46.3 \%$ in 2020. The achievement of this goal is expected to support the empowerment of many economically active poor and disadvantaged Nigerians, facilitate their involvement in economic activities and enable them contribute to national economic growth and development. The EFinA report of 2012 access to financial services survey report puts the current financial exclusion rate at 39.7\%. (EfinA, 2013). This is a clear indication that Nigeria's implementation efforts are beginning to yield results. The Nigerian strategy defines clear objectives and sets specific targets across five primary products and services (payments, credits, savings, pensions and insurance) through a broad range of coordinated interventions with high priority on the following areas below

I. Transformation of the KYC \{know your customers makes regulation into a simplified risk-based tiered framework that allows individuals easy for those who do not meet formal identification requirements to enter the banking system. Giant strides have been made in this regard with the new KYC regulation already released to the banking industry.

ii. Development and implementation of a regulatory framework for agent banking to enable financial institutions deliver services through agents such as post offices, in locations that might otherwise be unprofitable to have mortar and bricks branches. 
iii. Development and implementation of National Financial Literacy Framework to guide the delivery of programmes that will increase the awareness of financial products and services with the ultimate goal of increasing sustainable users.

iv. Implementation of comprehensive Consumer Protection Framework to safeguard the interest of consumers of financial products and services and sustain confidence in the financial system. A renewed policy and regulatory focus has therefore been placed on Financial Consumer Protection to support prudential measures and ensure increased consumer confidence and trust in a well-functioning financial system.

v. Consistent pursuance of adoption of mobile payment system and other cash-lite policy efforts to reduce the cost of service provision and increase the ease of financial service transactions.

vi. Implementation of credit enhancement schemes/programmes to empower micro, small and medium enterprises (SMMEs).

According to the 2012 Access to financial services in Nigeria Survey carried out by EFinA, 39 million adults (46.3\% of the adult population) were financially excluded (EfinA 2013). The 2012 Survey of the organisation showed that the exclusion rate had declined across geopolitical zones of the country as shown below:

\begin{tabular}{|l|c|c|c|}
\hline $\begin{array}{l}\text { Geo-political } \\
\text { Zone }\end{array}$ & $\begin{array}{c}\text { 2010 Adult } \\
\text { Exclusion }\end{array}$ & $\begin{array}{c}\text { 2012 Adult } \\
\text { Exclusion }\end{array}$ & $\begin{array}{c}\text { Percentage } \\
\text { Improvement }\end{array}$ \\
\hline North -East & 68.3 & 59.5 & 12.9 \\
\hline North -West & 68.1 & 63.8 & 6.3 \\
\hline North -Central & 44.2 & 32.4 & 26.7 \\
\hline South -East & 31.9 & 25.6 & 19.8 \\
\hline South -West & 33.1 & 24.8 & 25.1 \\
\hline South -South & 36.4 & 30.1 & 17.3 \\
\hline
\end{tabular}

Source: EFinA 2012 Survey Report

Notionally, the exclusion rate declined from $46.3 \%$ to $39.7 \%$ but there was still a problem. This huge percentage of excluded adult Nigerians, necessitated the launching of the strategy by the Central Bank of Nigeria (CBN), in collaboration with other stakeholders on $23^{\text {rd }}$ October, 2012. The broad target of the strategy is to reduce adult financial exclusion rate to $20 \%$ in 2020 . Out of the $80 \%$ to be included, $70 \%$ would be in the formal sector while $10 \%$ would be in the informal sector.

In terms of specific financial services, the following targets were set in the Strategy:

\begin{tabular}{|l|c|c|}
\hline Service Type & Level in 2010 & 2020 Target \\
\hline Payment Services & $21.6 \%$ & $70 \%$ \\
\hline Savings Services & $24.0 \%$ & $60 \%$ \\
\hline Credit Services & $2 \%$ & $40 \%$ \\
\hline Insurance Services & $1 \%$ & $40 \%$ \\
\hline Pension & $5 \%$ & $40 \%$ \\
\hline
\end{tabular}

Source; EFinA 2012 Survey Report

Furthermore, channels for outreach and provision of the services to increase in terms of units per 100,000 are as follows:

\begin{tabular}{|l|l|l|}
\hline Channel & 2010 & 2020 \\
\hline Branch of DMB & 6.8 & 7.8 \\
\hline Microfinance banks Branches & 2.9 & 5.0 \\
\hline ATMs & 11.8 & 59.6 \\
\hline Point of Sale (POS) Mobile Agents & 13.3 & 850.0 \\
\hline Mobile Agents & 0 & 62.0 \\
\hline
\end{tabular}

Source: EFinA 2012 Survey Report 
Major instruments to support the achievement of the stated targets were identified as follows:

i. Agent Banking - Agent banking is the delivery of banking services outside traditional bank branches, through additional touch-points such as existing retail stores and petrol stations or via technology such as Point of Sale (POS) devices or mobile phone.

ii. Mobile banking/Mobile Phone - Access to financial services through mobile phones that are either directly linked to a bank account or use of mobile wallets as intermediary virtual money accounts

iii. Linkage Models - Enhancement of financial and business cooperation between conventional financial institutions and (deposit money banks and development finance institutions/government and microfinance banks/institutions for wholesale funding and on-lending transactions.

iv. Client Empowerment - Increase in the bankability of the population through coordinated national financial literacy initiatives that are complemented with consumer protection.

In addition to the above appropriate guidelines and frameworks on Tier KYC requirement, agent banking regulation, national financial literacy framework, consumer protection, mobile payment guidelines and other cash-less effort are to be put in place.

\section{FRAMEWORK AND IMPLEMENTATION WITHIN THE NIGERIAN CONTEXT}

Nigeria prides itself as the most populated country and the economic giant of the African continent with over 205 million people but however about 64\% (of the adult population) is currently unbanked. The financial sector boasts of 22 commercial banks, over 400 microfinance banks and over 23 Mobile Money Operators, and over the years, they have been trying to tap into the market potential of the large unbanked population in the economy. The current unbanked population controls majority of daily retail transactions and even the banked population are encouraging them through cash transactions because the economy has not moved away from the traditional cash based operations. The result is the increasing number of informal financial operators whose activities are not regulated, but who control high volumes of liquidity which could have been used to create economic opportunities if it were in the hands of the formal financial institutions. The informal financial operators include the money lenders, informal loan cooperatives, thrift schemes such as Esusu in West Africa and Stokvels in South Africa where members are only entitled to the extent of their contribution. There are no checks and balances or any structured regulation in place to effectively manage or invest the available funds. Financial Inclusion is becoming a priority for policy makers, regulators and development agencies globally. The World Bank Group considers Financial Inclusion a key enabler to reducing extreme poverty and boosting shared prosperity, and has put forward an ambitious global goal to reach Universal Financial Access (UFA) by 2020. Since 2010, more than 55 countries have made commitments to Financial Inclusion, and more than 30 have either launched or are developing a national strategy. A recent World Bank research on Financial Inclusion indicates that when countries institute National Financial Inclusion Strategy, they increase the pace and impact of reforms.

Nigeria, through its Central Bank (CBN), has developed its National Financial Inclusion Strategy (NFIS) to provide the blue print which will guide and support stakeholder activities in advancing Financial Inclusion in the country. Some of the features of the strategy are stated below:

- Firstly, the target set for the strategy nationally is to reduce the percentage of adult Nigerians that do not have access to financial services from $46.3 \%$ in 2010 to $20 \%$ in 2020. In addition, the strategy projected that $70 \%$ of adult Nigerian should have access 
to payment services in $2020,60 \%$ to savings and $40 \%$ each to credit, insurance and pensions.

- Secondly, in order to achieve the above targets, the channels through which people can access the services such as branches of banks, microfinance banks, number of ATMs, mobile agents, Point of Sale (POS) agents of deposit money banks are also expected to increase to specified numbers per 100,000 adults in 2020. Accordingly, stakeholders are being encouraged and coordinated to ensure that the channel targets are met, while the Nigerian public is being sensitized to demand for, access and use the services available at these channels.

- Thirdly, regulators are being encouraged to develop relevant guidelines that will ensure that the number of access points increase. In this regard, the Central Bank of Nigeria has issued guidelines on the agent banking and mobile money operations, both of which will make financial services available at point so that the conventional branches that are often far and difficult to reach by consumers of these services. The Bank has also issued the tiered know your customer (KYC) requirements with simple documentation requirements, and by so doing, enables low income and rural dwellers to open and operate bank accounts. The financial literacy programme of the Central Bank of Nigeria in collaboration with the Federal and State Ministries of Education was established to implement financial literacy curricula in schools, as well as the collaboration between CBN and financial services providers to implement financial literacy campaigns. This will enlighten both providers and the public on possible financial services and how best they can be provided and accessed. Furthermore, the consumer protection programme will ensure that there is fair treatment of all customers.

\section{CURRENT IMPLEMENTATION STATUS}

The Nigeria's Financial Inclusion Strategy (NFIS) which was launched in 2012 sets out certain initiatives aimed at improving Financial Inclusion in the country. Various stakeholders engaged in the finance sector are implementing these initiatives. Financial Service providers have engaged in Financial Inclusion campaigns to capture the untapped working populations. The Bank of Industry (BOI) in 2015 launched the Bank of Industry Fashion Fund. Under the scheme, women entrepreneurs in the fashion industry can apply for up to N1,000,000 (One Million Naira) without collateral to invest in their fashion businesses. Access to such a scheme would likely require one to own a bank account with a commercial bank. Other financial institutions in Nigeria have also launched some initiative or strategy aimed at improving Financial Inclusion in the economy.

Regulators of the Finance Industry (CBN, PENCOM, NIC, NCC, NDIC, SEC etc.) are not left out as they have a key role to play in this regard. Since the launch of the NFIS in 2012 the CBN has embarked upon and implemented the following initiatives aimed at improving Financial Inclusion in Nigeria:

- Guidelines on Mobile Money Services(Guidelines) in Nigeria.-Issued in 2015

- Regulatory Framework for licensing Super-Agents in Nigeria-Issued in 2014

- Consumer Protection Framework - Issued in2016

- Bank Verification Number(BVN) Project Exercise - Introduced in 2014

- Three Tiered Know Your Customer(KYC) Requirements - Introduced in 2013

- Cashless Policy

- A financial literacy framework

Other regulatory bodies such as the National Pension Commission (PENCOM) and National Insurance Commission (NIC) have embarked on financial literacy awareness campaigns enlightening consumers on the benefits of the services offered within their industry, as well as 
law reforms that would promote Financial Inclusion within the Nigerian economy. In this regard, the subsequent review of the Pension Reform Act (PRA) 2004 and the enactment of the PRA2014 introduced the Contributory Pension Scheme (CPS) which made it mandatory for employers and employees in both the public and private sectors to contribute towards employee retirement benefits. The new pension scheme introduced an autonomous tripartite system involving The Regulator, The Administrator and The Custodian to minimise the possibility of misappropriation of pension funds in order to ensure that a large number of the population have adequate access to investible funds and lower rate credit facilities. Furthermore, the National Insurance Commission has also introduced the Micro Insurance and Takaful Insurance Guidelines which are to aid the achievement of Financial Inclusion in all sectors of the economy. The Minister for State for Finance, Dr. Yerima Lawan Ngama in a keynote address at a two-day Micro Insurance and Takaful Insurance Stakeholders Engagement Workshop and the official launching of the Takaful Insurance Guidelines in Lagos said the step taken by the Commission will further increase insurance penetration level and also contribute to the nation's GDP.

\section{ECONOMIC BENEFITS AND IMPACT}

The effort put in by the Nigerian government and the CBN to increase Financial Inclusion through the years has resulted in not just an increase in the number of people utilizing financial services but also in the growth and sophistication of the financial system. Furthermore, development economists have since established that Financial Inclusion leads to overall economic growth and development. In other words, them or financial inclusive markets are linked with better economic development, the more the increase in growth of the economy. The impact of Financial Inclusion can be accessed through various spectra of financial products offered to consumers including the following:

- Credit - Access to credit helps to encourage investments in assets that en able business owners to start or expand small enterprises. For instance, in 2016, "Enhancing Financial Innovation andAccess"(EFInA) awarded a \$2 million grant to First City Monument Bank (FCMB) to extend banking services to the financially excluded population in Nigeria. EFInA, a financial sector development organization that promotes Financial Inclusion in Nigeria, said the grant would enable FCMB, via its Group Lending and Agency Banking project, provide financial services and access to credit facilities to prospective customers in 12 states ;namely, Bauchi, Kaduna, Sokoto, Niger, Kwara, Lagos, Oyo, Ogun, AkwaIbom, Rivers, Cross River, and Abia

- Savings-Studies on the impact of savings show that savings help households manage cash flow spikes and smooth consumption, as well as build working capital. Compared to informal means of savings, saving at formal financial institution can be safe as deposits are insured up to a limit by the Nigeria Deposit Insurance Corporation (NDIC) and more valuable because of interest earnings. At macroeconomic level, saving scan lead to higher productivity and economic growth if they are invested within the country.

In view of the above, the National Financial Inclusion Strategy defined several initiatives to drive the achievement of the target for savings, including the implementation of the tiered

KYC requirements, the implementation of a national savings mobilization programme and policies to support linkages to informal savings groups. The prospects of achieving the savings target will depend to a large extent on the implementation of a national savings mobilization programme, the three-tiered KYC requirements, concerted implementation of the Digital Financial Inclusion Project, and the development of a formal framework on linkages between 
informal and formal financial institutions. Also, the mobile money accounts and agent banking initiatives need to be enforced by regulators and services providers.

- Insurance - Vulnerability to risk and the lack of instruments to cope with external shocks make it difficult for poor people to escape poverty. Micro insurance can be an important instrument for mitigating risk. Micro insurance is insurance that is usually accessed by low income earners in the society. Another aim of the product is to ensure everybody is included under the scheme and to increase the contribution of insurance to the country's Gross Domestic Product. An example is the recent introduction of the "Micro Insurance and Takaful Insurance Guidelines" by the National Insurance Commission which was laid down to aid the achievement of Financial Inclusion in all sectors of the economy.

- Electronic Payment and Mobile Money - An efficient payment system reduces incidental transaction costs. Rather than travel long distances, people have the ease of doing business on their mobile phones and other computer devices which is more cost effective Key initiatives to drive usage of electronic payment channels among Nigerian adults, as mentioned in the National Financial Inclusion Strategy, include the implementation of the tiered KYC requirements, the roll-out of the Cashless Nigeria Project in all States of the Federation, and programmes to increase public awareness about mobile payments. The three-tiered KnowYour Customer (KYC) requirements were introduced in 2013 to simplify account opening requirements. The requirements state that accounts of all three tiers can be opened with basic personal information and without any minimum amount. The primary aim of these initiatives is to increase the number of adult Nigerians that have access to financial services via the use of electronic payments in order to reduce inefficiencies, leakages and illicit financial flows in the financial system.

In addition, more inclusive financial markets are directly linked with economic growth and employment. Policy makers increasingly recognize that a financial market that reaches all citizens allows for more effective execution of other social policies and development priorities.

\section{India}

\section{OTHER COUNTRIES EXPERIENCES ON FINANCIAL INCLUSION}

India is one of the largest and fastest growing economies of the world, but what has been the most disturbing fact about its growth is that its growth has been sluggish and disconnected. There has been no uniformity in its growth performance and moreover growth and distribution of growth benefits to certain sectors of economy are very glaring. Further, a vast majority of the population remained outside of basic health and education facilities during her high growth phase. In recent decades, economic and social inequalities have increased alongside high growth rates which have increased regional inequalities. Over $25 \%$ of Indians continue to live in poverty. Rapid and sustained poverty reduction requires inclusive growth that allows people to contribute to and benefit from economic growth, As a result, Inclusive growth has become a national policy objective of the Union Government in India. In context of Indian growth planning it is a relatively new terminology which got the attention of policy makers in the Eleventh Five Year Plan of India. The extent of financial exclusion in India is found to be higher as compared with many Developed and some of the major emerging economies. The wide extent of financial Exclusion in India is visible in the form of high population per bank branch and low Proportion of the population having access to basic financial services like savings accounts, Credit facilities, and credit and debit cards. (Garg\& Parul, D. (2014).[18] The following table summarises India's performance in the area of financial inclusion as compared with other developing as well as developed countries. 


\section{Financial Inclusion: Current Status - India:}

\begin{tabular}{|l|l|l|l|l|}
\hline & \multicolumn{3}{|l|}{ Geographic Penetration } & \multicolumn{3}{l|}{ Demographic Penetration } \\
\hline Country & $\begin{array}{l}\text { No. of bank } \\
\text { branches per 1000 } \\
\text { sq km }\end{array}$ & $\begin{array}{l}\text { of ATMs } \\
\text { per 1000 sq km }\end{array}$ & $\begin{array}{l}\text { No. of ATMs } \\
\text { branches per } \\
100,000 \text { people }\end{array}$ & $\begin{array}{l}\text { Nor 100,000 } \\
\text { people }\end{array}$ \\
\hline Korea & 65.02 & 436.88 & 13.40 & 40.03 \\
\hline U.K & 45.16 & 104.46 & 18.35 & 42.45 \\
\hline India & 22.57 & - & 6.30 & - \\
\hline $\begin{array}{l}\text { Indonesi } \\
\text { a }\end{array}$ & 10.00 & 5.73 & 8.44 & 4.84 \\
\hline USA & 9.81 & 38.43 & 30.86 & 120.94 \\
\hline Mexico & 4.09 & 8.91 & 7.63 & 16.63 \\
\hline Brazil & 3.05 & 3.72 & 14.59 & 17.82 \\
\hline China & 1.83 & 5.25 & 1.33 & 3.80 \\
\hline Russia & 0.19 & 0.53 & 2.24 & 6.28 \\
\hline
\end{tabular}

Source: India Review of Initiatives and Achievements. IOSR Journal of Business and Management, 61

Despite various measures for financial inclusion, poverty and exclusion continue to dominate socio-economic and political discourse in India even after six decades of post economic independence era.

Though economy has shown impressive growth during post liberalization era of 1991, impact is yet to percolate to all sections of the society and therefore India is still home of $1 / 3$ of world's poor. Census, 2011 estimates that only 58.7\% of the households have access to banking Services.

The present banking network of the country (as on 31.03.2014) comprises of a bank branch network of 1,15,082 and an ATM network of 1,60,055. Of these, 43,962 branches (38.2\%) and 23,3341 ATMs (14.58\%) are in rural areas.

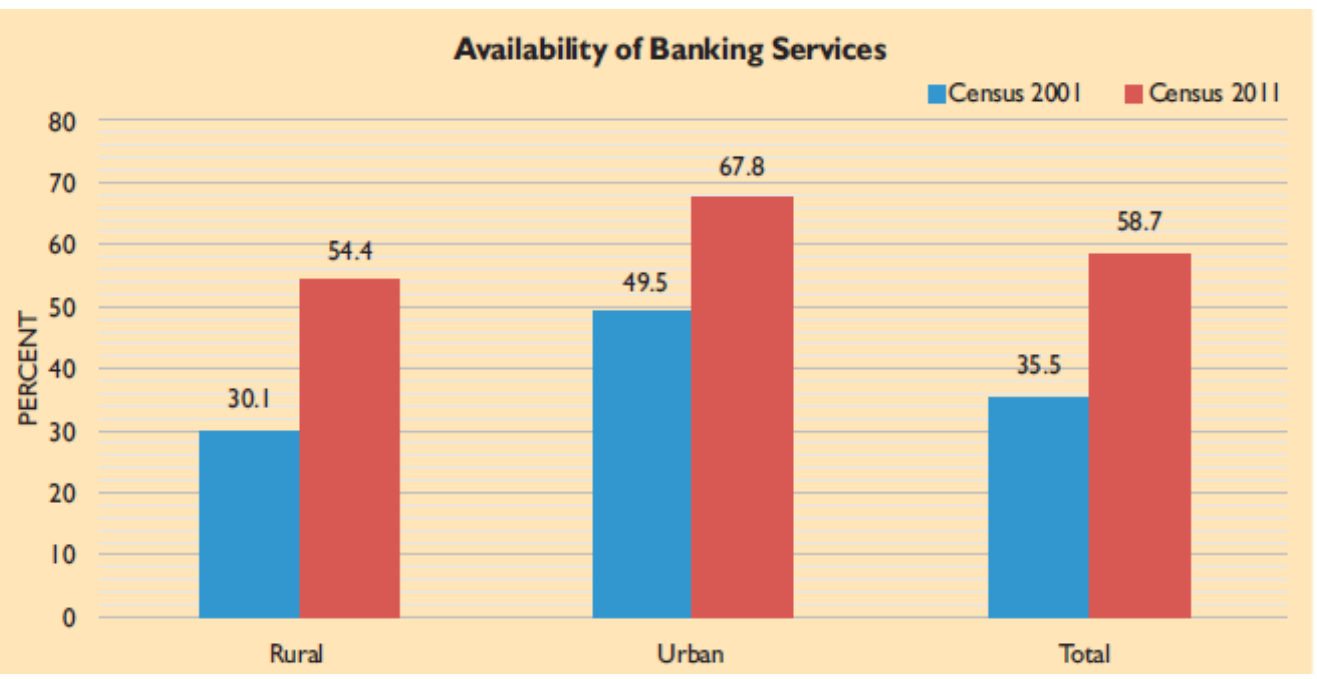

Source: India Review of Initiatives and Achievements. IOSR Journal of Business and Management, 61 
The summary of the progress of financial inclusion of all Banks in India including Regional Rural Banks (RRBs), during the five years period are as shown below. The statistics show that there is substantial progress towards opening of accounts, providing basic banking services during the recent years as indicated above. However, it is essential that all the sections be financially included in order to have financial stability and sustainability of the economic and social order. Only 35\% of Indian adults had access to a formal bank account and $8 \%$ borrowed from a formal financial institution in last 12 months. The minute number suggests an urgent need to further push the financial inclusion agenda to ensure that people at the bottom of the Pyramid join the mainstream of the formal financial system.

\begin{tabular}{|c|c|c|c|c|c|}
\hline Particulars & \begin{tabular}{|l|} 
year \\
ended \\
2010
\end{tabular} & \begin{tabular}{|l|} 
year \\
ended \\
2011 \\
\end{tabular} & \begin{tabular}{|l|} 
year \\
ended \\
2012 \\
\end{tabular} & \begin{tabular}{|l|} 
year \\
ended d \\
2013
\end{tabular} & \begin{tabular}{|l|} 
year \\
ended \\
2014 \\
\end{tabular} \\
\hline \multicolumn{6}{|l|}{ banking outlets in villages } \\
\hline a)Branches & 33,378 & 34811 & 37471 & 40837 & 46126 \\
\hline b) Villages covered by BC's & 34174 & 80802 & 141136 & 221341 & $3,37,678$ \\
\hline c)Other Modes & 142 & 595 & 3146 & 6276 & \\
\hline total & 67674 & 116208 & 181753 & 268454 & 383804 \\
\hline Urban location through BC's & 447 & 3771 & 5891 & 27143 & 60730 \\
\hline \multicolumn{6}{|c|}{ Basic saving bank deposit a/c - branches } \\
\hline a )No.in. Millions & 60.19 & 73.13 & 81.2 & 100.8 & 126 \\
\hline b)Amt.in .billions & 44.33 & 57.89 & 109.87 & 164.69 & 273.3 \\
\hline \multicolumn{6}{|c|}{ Basic saving bank deposit a/c- BC's } \\
\hline a) No.in.Millions & 13.27 & 31.63 & 57.3 & 81.27 & 116.9 \\
\hline b)Amount in billions & 10.69 & 18.23 & 10.54 & 18.22 & 39 \\
\hline \multicolumn{6}{|c|}{ OD Facility availed in BSBDA's Account } \\
\hline a)No.in.millions & 0.18 & 0.61 & 2.71 & 3.92 & 5.9 \\
\hline b)Amt.in .billions & 0.1 & 0.26 & 1.08 & 1.55 & 16 \\
\hline KCC's(No.in.Milions) & 24.31 & 27.11 & 30.24 & 33.79 & 39.9 \\
\hline
\end{tabular}

Source: India Review of Initiatives and Achievements. IOSR Journal of Business and Management, 61

\section{Progress of Financial Inclusion Initiatives in India}

Due to RBI's concerted efforts since 2005, the number of branches of scheduled Commercial Banks increased manifold from 68,681 in March 2006 to 1, 02,343 in March 2013.In rural areas, the number of branches increased from 30,572 during March 2006 to 37,953 in March 2013. As compared with rural areas, number of branches in semi-urban areas increased more rapidly.

Total number of banking outlets in villages increased from 67,694 in March 2010 to 2,68,454 in March 2013 (increased around 4 times during the period of three years) of total branches, banking outlets through BCs increased from 34,174 to 2,21,341 during the same period (increased around 6.5 times). The number of Basic Savings Bank Deposit Accounts opened increased from 73.45 million in March 2010 to 182.06 million in March 2013.RBI advised banks to provide small overdrafts in BSBD accounts. Accordingly up to March 2013, 3.95 million BSBD accounts availed OD facility of Rs. 1.55 billion (These figures respectively, were 0.18 million and 0.10 billion in March 2010).Banks have been advised to issue KYCs to small farmers for meeting their credit requirements. Up to March 2013, the total number of KYCs issued to farmers remained at 33.79 million with a total outstanding credit of Rs.2622.98 billion. Banks have been advised to introduce General Credit Card facility up to Rs. 25,000/- at their rural and semi-urban branches. Up to March 2013, banks had provided credit aggregating 
to Rs.76.34 billion in 3.63 million GCC accounts. (Garg, et al (2015) [18] and World Bank (2008)[34].

\section{Mexico}

The Federal Government of Mexico established Development National Plan for 2007 - 2012 as policy agenda for increasing the level for financial inclusion, strengthen consumer protection and to enhance financial literacy in the country. The Secretariat of Finance and Public Credit works closely with supervisory agencies, the Central Bank of Mexico, the National Savings Bank and legislators, among others to keep financial inclusion as a priority on the policy agenda. In 2008, the Mexican Congress approved a reform for their banking law in order to enable the use of non-financial entities to serve the as banking agents and allow the establishment of Specialised Banks. (Niche Banks) in order to increase access to the financial services. The National Banking and Securities Commission of Mexico issued operational rule for the use of non-financial entities as banking agents to provide financial services to the underserved regions. To expand their services to the unbanked rural areas, savings and credit institutions received assistance to become formal regulated institutions and accept deposits. They are supported by National Savings and Financial Services Bank. The later provides back-office and banking services to these institutions in close cooperation with the Federal Secretariat of Finance and Public Credit, National Banking and Securities Commission and the Secretariat of Agriculture, Livestock, and Rural Development. (World Bank, 2014) [35]. (Grag.2014).

\section{Pakistan}

In Pakistan, there a board based political commitment to financial inclusion with the State Bank of Pakistan at the forefront. A wide range of policy makers are supporting the commercialisation of microfinance industry, fascinating competition, innovation and diversification of product service delivery channels in the country The first Microfinance Bank Limited has partnered with Pakistan Post to use their infrastructure for expanded outreach on financial services. There are also financing facilities and funds for institutional strengthening for microfinance and guidelines for Microfinance Banks and Microfinance institutions. Microfinance share information with their customers through private credit information Bureau with necessary privacy safeguards.

The State Bank of Pakistan has received guidelines for regulation of financial services through agents and mobile phones. The Ministry of Finance has recommended consistent tax treatment for mobile banking operations to support national outreach to rural and remote areas. The Pakistan Telecommunication Authority has also regularized registration and annual license fees on satellite communication system and other technologies that support outreach to remotely located clients.. (World Bank, 2008) [34].

\section{Kenya}

The financial inclusion goal in Kenya's Vision 2030 Strategy empowered the Central Bank of Kenya to play an active role in expanding access through regulating and supervising commercial banks. In $2009-2010$, the Bank identified two areas which have a dramatic impact on reducing the costs of delivering financial services through the banking system These include the introduction of agents for use by the banks to deliver their services and the revision of current regulations and guidelines related to branch outlets.

Presently, Kenyais recognized as a pioneer in mobile phone financial services through the "MPesa" mobile payment system which had 17 million subscribers as at December, 2011. It is the most developed mobile payment system in the world that allows subscribers to deposit, 
withdraw and transfer money easily with a mobile device. (Allen et al (2013).[05] and Aduda et al (2012) [01].

\section{The Philippines}

Four million unbanked Filipinos are seen to benefit from the nascent credit scoring industry, a development that is seen to serve the person that is classified at the bottom of the economy an easy access to credit once the service is available to the public. Marlo R. Cruz, president and chief executive officer of CIBI Information, Inc. (CIBI) as one of the accredited credit bureaus in the Philippines, highlighted that this is expected to unlock much economic potential in sectors of the economy that are crucial for inclusive growth.[9]

As per Cruz, "Many people still do not realize that the value of having a credit opportunity is synonymous to generating financial power. Creditworthiness is the same as to owning a key card that can be used in navigating to the society of better possibilities." [10]

The Bangko Sentral ng Pilipinas (BSP) reports on Financial Inclusion Initiatives and Financial Inclusion in the Philippines summarizes the country's accomplishments and significant milestones in financial inclusion. These reports show that 4 out of 10 Filipinos saved money in 2015 (up from 2 out of 10 in 2009). Among Filipino adults, 24.5\% never saved and only 31.3\% (up from 26.6\%) have an account at a formal financial institution. The lack of enough money was cited as the main reason for not having a bank account.[11]

While there has been significant progress, there is still much to be done.

As an emerging country with a sizeable number of people living in poverty, access to financial services is an important challenge. Based on a March 18, 2016 report from the Philippine Statistics Authority, the country's 2015 poverty incidence (the proportion of people below the poverty line versus the total population) is at $26.3 \%$ while the subsistence incidence (the proportion of Filipinos in extreme or subsistence poverty) is at $12.1 \%$. This means that there are around 26 million Filipinos who are still living below the poverty line. The Central Bank of the Philippines has also been involved in dialogue with the Rural Bankers Association of the Philippines to allow the launch of an innovative application using mobile money. (Global Data base (2015) [19] and World Bank (2008). [34].

\section{THE CHALLENGES OF FINANCIAL INCLUSION STRATEGY IN NIGERIA}

As earlier stated, over half of the world's adult population does not have access to formal financial institutions. Improving the global average level of Financial Inclusion has therefore become a global challenge as this poses a threat to global economic growth and development.

In Nigeria's context, it is quite clear that to cover Nigeria with a very large population of about 205 million with a sustainable financial services especially banking services is extremely a difficult task.. Both demand side factors (customers) and supply side factors (banks and other financial institutions) are responsible for financial inclusion. Banks and other financial institutions are largely expected to reduce the supply side constraint which includes nonavailability of branches in rural area; high rules and regulations and high bank charges. There are also limited number and types of financial service providers compared with the population of Nigeria.

The demand side challenges include but not limited to: low literacy levels, lack of awareness of about financial products and services, irregular income of the economically active poor and 
disadvantaged, lack of trust and confidence in formal banking institutions etc. The following are some of the key challenges that hinder Financial Inclusion in Nigeria:

- Low Literacy Levels - Given the fact that more than half of the adult population in Nigeria is uneducated, it stands to reason that this group of Nigerians also lack knowledge of the benefits derivable from accessing financial services. Furthermore, staff off in ancial service providers also seems to display a lack of adequate understanding of the financial services they offer and are unable to educate the unbanked effectively. We recommend that Government should embark on awareness initiatives in local languages to cater to the gap in the adult population. Financial service providers on their part have to provide on-going training to their staff.

- Poverty and Unemployment - Increasing poverty and unemployment are another major impediment to Financial Inclusion in the country. As these increase, more of the adult working population is less inclined to utilise financial products and services. The Government on its part has to create an enabling environment for businesses to thrive which will in effect lead to more job creation within the Nigerian economy.

- Inadequate/Inefficient Financial Service Infrastructure - Also of greater once rnis the largely inefficient e-channel service of most of the deposit money banks. The various echannels and applications such as ATM, POS and mobile banking platforms that are supposed to facilitate electronic transactions have remained deficient in most cases. ATM card requests stay untreated for weeks and months, while most subscribers to Internet and mobile banking platforms complain of poor services. This challenge manifests itself generally in form of inadequate financial infrastructure especially in the rural areas where the bulk of the financially excluded are found and therefore limits options for accessing financial services. Financial service providers must invest in infrastructure and ensure that regular maintenance and upgrade is conducted whilst improving custom relations.

The above are some of the demand-side challenges to Financial Inclusion in Nigeria. The supply- side challenges include long distance to financial access points, the prohibitive cost of financial services and inappropriate financial products, etc.

Regulatorybarriersincludethecumbersome "KnowYourCustomer"(KYC)requirements,lackof adequate laws and regulatory framework that would promote access to financial services. Other challenges include lack of trust in financial services providers and high rates of corruption in the country.

\section{RECOMMENDATIONS FOR IMPROVING FINANCIAL INCLUSION IN NIGERIA}

Some of these measures are recommended for achievement of greater financial inclusion in Nigeria as stated below:

i. The government should consider tying up with Private banks to deliver financial solutions to the un-banked, using its extensive postal network and corporate agencies.

ii. The rural poor have irregular/volatile income streams and expenditure needs, and therefore, prefer to borrow frequently, and repay in small instalments. There is need for the Government to encourage the poor by reflecting this in the regulatory framework of microfinance banks and ensures its implementation and stability of the microfinance insti-----------------------tutions.

iii. There is a need for composite financial servicesand also creating its awareness to the masses. While small rural borrowers seek savings and lending services, they also seek insurance (life, health, crop insurance, etc). Some big bank branches in rural areas would do well to explore opportunities to offer composite financial services. 
iv. Setting of Biometric ATMs in rural areas for catering to illiterate customers and at the same time educating them on how to use them by reliable and competent bank workers attached to those rural branches to minimize exposures to fraudsters.

v. There is a need of building an interactive internet based system by which the banks could be able to understand the queries of people living in rural areas.

vi. A lack of legal documentation is another major obstacle that poor households employed in the informal sector face when trying to open any kind of bank account, be it savings, credit, or current account. Simplification of procedures could also go a long way in encouraging the poor to bank with the formal sector, by reducing clients' transaction costs.

vii. Public sector banks like specialised institutions currently do not have the flexibility to recruit staff locally, but staffing policies could be revisited. It is worth noting in this context that the high recovery rates of microfinance are associated with staffing policies that allow recruiting staff from the local area who understand clients' needs, and a focus on doorstep banking.

viii. Removing usage fee on ATMs for use of other Bank ATM. This a double chare on the part of customers. The regulatory authority should see that banks do not impose such charges and should penalized for such activity.

ix. The Government should provide free public capacity building on the importance financial literacy and customer protection framework for the rural area dwellers which will eradicate financial literacy and also encourage the poor to save, borrow and reinvest for their benefit and growth and development of the economy

x. Banks should providing Basic Banking Accounts with overdraft facility of up to a stated reasonable amount to encourage the poor. .

xi. To ensure that persons belonging to low income group do not face difficulty inopening bank account due to procedural hassles, Banks should not insist on minimum amount to open savings account to enable excluded open a savings account. No-specific account savings balance requires no negligible balance. This leads to lower costs both for the bank and individual.

xiii. banks should provide all the material related to opening accounts, disclosures etc in the regional language.

\section{CONCLUSION}

In light of the above, there is no doubt that inclusive growth depends mainly on equitable distribution of growth benefits and opportunities to all that need the benefits. Financial Inclusion is one of the most critical parts which need to be equitably distributed in the country in order to attain comprehensive growth and development within the Nigerian economy. Financial Inclusion is integral to any nation's economic development, especially for developing countries like Nigeria. Greater Financial Inclusion is achieved when very economic activity, geographical region and segments of the society have access to financial information, financial assistance, financial services and financing with ease and at minimal costs. This helps promote balanced growth through the process of facilitating savings and investment and thus causing efficient resource allocation from surplus sectors of the society to deficit sectors of the society. By this process, financial transactions are made easy, income level and growth increases with equity, and poverty is eliminated, while the economy becomes insulated from external shock.

Furthermore, this paper compared Nigerian financial inclusion strategy with other emerging economies in the upper middle income strata. There is an implicit believe that Nigerian financial inclusion indicator is still shallow when compared with emerging economies both within and outside Africa. There is need for the government and other stakeholders to understand fully that to achieve sustainable higher growth, there should be inclusive financial 
services extended to all, irrespective of all groups of people, especially to the economically active poor and the disadvantaged .Achieving greater Financial Inclusion is a responsibility of all relevant stakeholders and involves collective effort. However, the onus is on the government to make the first step towards Financial Inclusion by establishing a sustainable and necessary institutional framework, an effective regulatory framework and an environment necessary for success and full implementation of any Financial Inclusion strategy. As mentioned earlier, the Federal Government, through the Central Bank of Nigeria, has gone about this by in augurating the National Financial Inclusion Strategy in 2012 and several other initiatives a imedat improving Financial Inclusion. The government must be commended for its progress thus far but must continue and intensify her effort to engage stakeholders and create the necessary environment for financial stability. Stakeholders such as commercial banks, insurance firms, agents and other financial service providers must adhere to requirements and regulations set by the CBN. They must also endeavour to engage potential financial service on summers, as they are the main tool for widening the coverage of financial services in the country.

\section{References:}

Aduda J, Kalunda E (2012) Financial inclusion and financial sector stability with reference to Kenya: A review of literature, Journal of Applied Finance and Banking 2: 95-120.

Afangideh, U. J. (2010). "Financial Development and Agricultural Investment in Nigeria: A Historical Simulation Approach" Journal of Economic and Monetary Integration, 9(11)74 -94.

Afi, (2010). "A Survey on Financial Inclusion Policy in Developing Countries: A Preliminary Findings" Alliance for Financial Inclusion (April).

Ajakaiye, D. O. (2013). Financial Inclusion in Nigeria: Measurement and Lesson. Bullion. July, 2012 - March, 2013. Vol.36 No.3 - Vol.37, No.1 (CBN Publication, Abuja)

Allen F, Carletti R, Cull J, Qian L, Valenzuela P (2013) Resolving the African financialdevelopment gap: Crosscountry comparisons and within-country study of KenyaWorld Bank Policy Working Paper 6592, Washington, DC.

Anupama, S., \& M. Sumitha, K. (2013). "An Analytical Study of Relevance of Financial Inclusion for developing Nations". IOSR Journalof Business and Management, 61.

Archana, H. N. (2013). "Financial Inclusion: Role of Institutions"Innovative Journal of Business and management, 47.

Bank of India (2013) Sustainable financial inclusion in India. Publication ofReserve Bank of India.

Baran, P.A. (1968): The Political Economy of Growth, New York, Monthly Review, Inc.

Brune L, Giné J, Goldberg D, Yang T (2011) Commitments to save: A field experiment in rural Malawi. World Bank Policy Research WorkingPaper 5748. Washington, DC.

CBN.(2005). Microfinance Policy Regulatory and Supervisory Framework for Nigeria. (CBN Publication Abuja).

CBN (2012). National Financial Inclusion Strategy. Central Bank of Nigeria, Abuja.

Chakrabarty, K. C. (2012). "Financial Inclusion: Issues in Measurement and Analysis". Key note Address at the Bank for International Settlement, Central Bank of Malaysia Workshop.

Collins, D and J. Morduch, S. Rutherford, and O. Ruthven. (2009). "Portfolios of the Poor: How the World's Poor live on Two Dollars Day". Princeton, NJ, Princeton University Press..

Cyn-Young P, Rogelio V (2015) Financial inclusion, poverty, and income inequality in developing Asia, Asian Development Bank Economics Working Paper Series.

Demirguc-Kunt, A and Klapper, L (2012). "Measuring Financial Inclusion: The Global Findex Database". The World Bank Development Research Group. WPS6025.

Eluhaiwe, P. N. (2013). "Financial Inclusion Initiatives and NationalEconomic Development" Bullion. July, 2012 March, 2013., Vol.36, No.3 - Vol.37, No.1 (CBN Publication, Abuja). 
EFinA. 2013. Enhancing Financial Innovation and Access. EFinA Access to Financial Services in Nigeria, 2012 Survey Report, May.

Gardeva, A. and Rhyne, E (2011). “Opportunities and Obstacles to Financial Inclusion”, Centre foe Financial Inclusion.

Garg, S., \& Parul, D. (June 2014), Financial inclusion in India Review of Initiatives and Achievements. IOSR Journal of Business and Management, 61.

GlobalFinancialDatabase(2015)Retrievedfrom http//www.data.worldbank.org/data-catalog/financial_inclusion Goldsmith, R. W. (1969).“Financial Structure and Development”. New Haven, Yale University Press.

Greenwood, J. and Jovanovic, B. (1990). "Financial Development, Growth and Distribution of Income” Journal of Political Economy. Vol.37, (465 - 475).

Joseph J, and Varghese T (2014) Role of financial inclusion in the development of Indian economy. Journal of Economics and Sustainable Development 5: 6-13.

Kelkar, V. (2009). "Financial inclusion for Inclusive growth”. ASC Journal of management. , 59.

Lipsey, R. (1982): “ An Introduction to Positive Economics”, London, ELDS and Weidenfeld and Nicolson.

Massey, J. (2010). “Role of financial institutions in financial inclusion”. www.google.com.www.rbi.gov.in.

Migap J, Okwanya I, Ojeka G (2015) Financial inclusion for inclusive growth: The Nigerian perspective. International Journal of Information Technology and Business Management 37: 1-8.

Nkwede F (2015) Financial inclusion and economic growth in Africa: Insight from Nigeria, European Journal of Business and Management 7: 2222-2839.

NSB-SMEDAN (2012). Nature and Number of Enterprises and Businesses. Source: 2010 National MSME. Collaborative Survey

Onaolapo A (2015) Effects of financial inclusion on the economic growth of Nigeria. International Journal of Business and Management Review 3:11-28.

Shittu, J. A. (2012). "Financial Intermediation and Economic Growth in Nigeria”. British Journal of Arts and Social Sciences, 4(2).

Todaro, M.P. (1980): “Economics for Developing World” Longma London.

Umma, Dutse. (2013). “The Role of Financial Literacy and Consumer Protection in fostering Financial Inclusion”. CBN Bullion. July, 2012 March, 2013., Vol.36 No.3 - Vol.37, No.1 (CBN Publication, Abuja).

Uwakaeme, O.S.(2015)."Economic Growth in Nigeria: An Empirical Investigation of Determinants and Causal Relationship." American Journal of Economics, Vol.5. Scientific and Academic Publishing,USA):

http://journal.sapub.org/economics. ISSN: 2166 -4951.

World Bank (2008).“Finance For All? Policies and Pitfalls in ExpandingAccess”. Washibgton, DC. World Bank.

World Bank (2014) Global financial development report 2014: Financial Inclusion, Washington, DC.

http://www.biia.com/philippines-the-road-towards-financial-inclusion 